\title{
Connecting worlds: indigenous territories, habitat suitability and conservation of three large carnivores (Mammalia: Carnivora) in southern Mexico
}

\author{
Emilia F. Guerrero-Montes de Oca ${ }^{1,2 *}$, Camilo Gómez Hoyos ${ }^{3}$, Fabián G. Mejía \\ Franco $^{3}$, Francisco Botello ${ }^{1}$, Víctor Sánchez-Cordero ${ }^{1 *}$ and Andrés Arias-Alzate ${ }^{3}$
}

\begin{abstract}
Human and wildlife conflicts pose conservation challenges for several charismatic species worldwide. Given their close and long-standing interactions with wildlife, indigenous communities set an interesting framework to identify factors establishing these relationships. The first step is to account the perceptions and symbolisms of indigenous communities to define and complement conservation efforts. We used multi-temporal and multi-criteria analyses to assess species habitat suitability of the jaguar (Panthera onca), puma (Puma concolor), and coyote (Canis latrans), and quantified the overlap with the Mixtec and Zapotec indigenous territories in Oaxaca, located in southern Mexico. We observed a positive and proactive relationship between indigenous communities' self-identification and a high species habitat suitability for the conservation of these large carnivores in the Sierra Norte, Sierra Sur, Coastal, and Mixtec regions. Given that most of these areas occur outside natural protected areas, the inclusion of indigenous communities in the management of their territory is crucial for preserving their ethnocentric vision and ensuring long-term conservation of these charismatic top predator species and their habitat.
\end{abstract}

Keywords: Human-Wildlife Conflict; Jaguar; Puma; Coyote; Indigenous Communities.

1 Departamento de Zoología, Instituto de Biología, Universidad Nacional Autónoma de México, Circuito Exterior s/n, Ciudad Universitaria, Coyoacán, C. P. 04510, Ciudad de México, México.

2 Posgrado en Ciencias Biológicas, Unidad de Posgrado, Edificio A, $1^{\text {o }}$ Piso, Circuito de Posgrados, Ciudad Universitaria, Coyoacán, C. P. 04510, Ciudad de México, México.

3 Facultad de Ciencias y Biotecnología, Universidad CES. Calle 10a \#22 - 04, Medellín, Antioquia, Colombia.

* Corresponding author $\bowtie$. E-mail address: EG-M (ef_guerrero@hotmail.com), VS-C (victor@ib.unam.mx)

\section{SIGNIFICANCE STATEMENT}

This study assessed from a spatial ecology perspective, the relationship between indigenous communities and the conservation of large carnivore species. We used a multitemporal and a multicriteria habitat suitability analyses to infer the habitat suitability of the jaguar (Panthera onca), puma (Puma concolor), and coyote (Canis latrans), and its association with two indigenous territories in southern Mexico. The findings showed a high geographic overlap of a positive and proactive relationship between indigenous communities' self-identification and a high species habitat suitability for the conservation of these large carnivores. The inclusion of the indigenous communities in conservation actions is a crucial step to ensure the preservation of their ethnocentric vision, and long-term protections of these charismatic top predator species. 


\section{INTRODUCTION}

The human population has been significantly increasing in the last 200 years along with an exponential demand for natural resources (FAO 2017). Rapid human population increase entailed overexploitation of natural resources, drastically degrading the landscapes and ecosystems. This has resulted in significant detrimental impacts on local indigenous communities, and the provision of environmental services and biodiversity conservation essential for their wellbeing (González-Maya et al. 2013; Ellis 2011; Ripple et al. 2014; Easter et al. 2020). The overexploitation of natural resources has increased human and wildlife conflicts worldwide, posing conservation challenges on several charismatic species. Further, the loss of large areas of ecosystems has reduced several environmental services of which indigenous communities are highly dependent (Redford 1992; Crooks 2002; Brooks et al. 2006; González-Maya et al. 2013; Williams et al. 2018). The consequences due to rampant natural habitat degradation have raised international concerns urging to establish conservation strategies that incorporate local inhabitants involved in programs of sustained use of natural resources and biodiversity conservation (United Nations 2019). However, some approaches to conservation were not adequately oriented so as to afford integral protection to biodiversity, it is necessary to include local inhabitants and their relationship with the environment (GonzálezMaya et al. 2013; Williams et al. 2018).

In Mexico, the indigenous communities cosmovision linked to biodiversity is in many cases preserved, and this includes charismatic species as large carnivores (Saunders 1994; Seller 2004; López Austin 2012, 2013; Sánchez and Durán 2018). However, regional conservation of biodiversity sets some challenges as local indigenous communities face cultural distortions, given the vision of some stakeholders to apply a strict economic use of natural resources and the expansion of areas for agriculture and livestock (Toledo 2001; Toledo and Barrera 2008; Descola 2001). For this reason, conflicts between the local indigenous communities and wildlife arise, particularly in areas where livestock losses occur due to large carnivores' predation (Guerrero-Montes de Oca et al. in preparation). Hence, conservation actions need to incorporate an integrated and participatory vision for preserving the biodiversity perceptions and historical symbolism of the indigenous communities. An integrated strategy needs to include the preservation of indigenous identity, sustainable use of natural resources, and conservation of biodiversity and ecosystems that provide critical environmental services to local inhabitants (Stevens 1997; Carabias et al. 2010; González-Maya et al. 2013).
The Mexican State of Oaxaca has been identified with a high diversity of multiculturality holding a high percentage of the indigenous population in Mexico. It is estimated that approximately $70-80 \%$ of its territory shows a collective self-attribution to one or another indigenous community (Galindo 2010), including two of the main ethnolinguistic groups, the Mixtecs (Ñu savi) and the Zapotecs (Binnizá, Bene Xon, or Ben'zaa) (INEGI 2015; INALI e INPI 2019). The Mixtecs and Zapotecs are among the most ancient groups in Oaxaca, where their presence has been recorded over the last 3,500 years. The Mixtecs are located in the Mixteca Alta, Mixteca Baja, and the Coastal Zone regions, and have been characterized by the depth and continuity of its beliefs (INALI e INPI 2019). The Zapotecs are the dominant group - in political, economic, and cultural spheres - in extensive regions of Oaxaca, including the Central Valleys and the Isthmus of Tehuantepec (Vela 2010; INALI and INPI 2019). For over 2,500 years, diverse records (e.g., sculptures and other artistic products, and narrative and mythical traditions) have been found documenting the positive and proactive vision of these ethnic groups on biodiversity and a close and long-standing interaction with large carnivore species occurring in Oaxaca (Guerrero-Montes de Oca et al. in preparation).

Oaxaca also holds an exceptional species richness and endemicity of flora and fauna, ranking top in terrestrial vertebrate species nationwide (GarcíaMendoza et al. 2004). It is considered a Mesoamerican biodiversity hotspot, although human-induced activities such as deforestation, livestock and urbanization expansion threaten its conservation (MonroyGamboa et al. 2019). However, Oaxaca includes few protected areas covering a small fraction of less than $5 \%$ of its territory and more recently a high number of conservation initiatives involving governmental agencies, non-governmental organizations, and local communities have established areas with specific objectives related to biodiversity conservation (MonroyGamboa et al. 2019).

We assessed the geographic overlap of two main indigenous groups (Mixtecs and Zapotecs) and the habitat suitability of jaguar (Panthera onca), puma (Puma concolor) and coyote (Canis latrans), three large top predators and charismatic carnivore species occurring in Oaxaca. Given that self-identification of these indigenous communities entails a proactive appreciation of biodiversity, we assumed that the overlap of suitable habitats with a high ethnocultural and biological value in the region provides a proactive scenario for the conservation of these large carnivore species. This is of particular importance not only for the long-term conservation, but also given that in this region decision-making on territorial planning 
and regulation involves over $70 \%$ of woodlands and tropical forests, which enter into the demarcations of ejidos and indigenous communities (Galindo 2010).

\section{MATERIAL AND METHODS}

\section{Study Area}

The study area is located in the State of Oaxaca in southern Mexico $\left(17.0732^{\circ} \mathrm{N}, 96.7266^{\circ} \mathrm{W}\right)$ with an area of $93,757 \mathrm{~km}^{2}$ (4.85\% of Mexico) (Figure 1). It is divided into 570 municipalities that are grouped into eight regions and 30 districts (INEGI 2017a). Oaxaca has a complex topographic and climatic composition, where the Sierra Madre del Sur and the Sierra Madre Oriental converge. Almost 70\% of the area of Oaxaca shows a tropical humid climate mostly located in northern, eastern, and coastal regions; $15 \%$ of the area shows a temperate humid climate located in the highlands of the Sierras $(>2000$ masl); $11 \%$ of the area shows a dry climate in the center and northwest regions. Annual mean temperature is $22^{\circ} \mathrm{C}$ (range $12-3^{\circ} \mathrm{C}$ ); annual mean precipitation is $1550 \mathrm{~mm}$. The complexity of topographic and climatic conditions has favored the existence of a high ecosystem diversity. For example, it is estimated that close to $80 \%$ of the 32 main vegetation types occurring in Mexico are represented in Oaxaca, including temperate humid montane forest, pine, pine-oak, and oak forests, tropical dry and humid forests, and xeric vegetation (García-Mendoza et al. 2004). Main anthropogenic activities include increasing agriculture, livestock, and urbanization threatening biodiversity conservation statewide (Monroy-Gamboa et al. 2019).

\section{Multi-temporal analysis of habitat suit- ability}

To evaluate the habitats' conservation status for jaguar, puma, and coyote and their relation with the Mixtec and Zapotec territories, we conducted a multi-temporal analysis of habitat suitability using a multi-criteria inferential analysis. Then, we overlap these areas with the decreed protected areas and with the distribution of the Mixtec and Zapotec ethnic groups, and their respective spatial pattern of self-identification. This allowed us to identify the areas showing a biological and cultural interaction, and therefore the priority areas of biocultural conservation (Toledo and Barrera 2008; Granados-Peña et al. 2014).

Specifically, we evaluated the suitable habitats availability for these large carnivore species using a multi-criteria inferential analysis performed with the overlay geoprocessing spatial analyst tool via map algebra expression in the ArcGis 10.5 program (ESRI 2011). This technique facilitates decision-making processes that integrate two or more variables, such as those that emerge in conflicts of environmental management, where many attributes and relations are considered, occurring at a particular time-space or different times-spaces (Tecle and Duckstein 1993; Martinez-Alier et al. 1998; Munda 2005). This analysis was conducted based on variables and values ranges, starting with landscape and land cover (urban areas, agricultural areas, natural forest, woods and natural forest, shrubland, wetlands, natural pasture, permanent cultivated pasture, low secondary shrub vegetation, secondary high arboreal vegetation, without apparent vegetation, and degraded areas), distance from water bodies and main roads, elevation and terrain inclination, distance from human populations, and population densities in Oaxaca (Table 1). We used the data layers for Land Use and Land Cover maps (LULC) at 1:250,000 scale (modified by CONABIO) for three time periods: LULC 2009, LULC 2013, and LULC 2016 (INEGI 2009, 2013 and 2016). We chose these time periods because these data layers are closely linked to the INEGI's 2015 Inter-Censal Survey and are the current official data layers available. Afterward, a significance assessment was conducted to these group of variables, where a range and a weight values were assigned to each group according to the information previously published for the species and based on expert knowledge (GonzálezMaya et al. 2010; Benítez et al. 2013, and GranadosPeña et al. 2014). These ranges were classified as not significant (1), little significant (2), neutral (3), significant (4), and very significant (5) (Table 1). The weight value was related to the importance of each group of variables according to the ecology and natural history of jaguar, puma, and coyote, respectively. This metric indicates the relative importance of each variable related to habitat use for each focal species. These weight values range from 0 to $100 \%$, and the sum of the total variables' percentage should reach $100 \%$ for each species (see Penrod et al. 2010) (Table 1). Subsequently, all these variables were rasterized and projected to World Mercator Datum WGS 1984 with a resolution of $500 \mathrm{~m}^{2}$. Then the resulting values were reclassified into three categories: high, medium, and low suitability values following published protocols (Rondinini et al. 2011; Crooks et al. 2017). This classification provides better understanding and criteria to select areas with suitable or unsuitable habitat conditions for a long-term occurrence and conservation of jaguar, puma, and coyote in Oaxaca. All these analyses were performed using the software ArcGis 10.5 (ESRI 2011). 

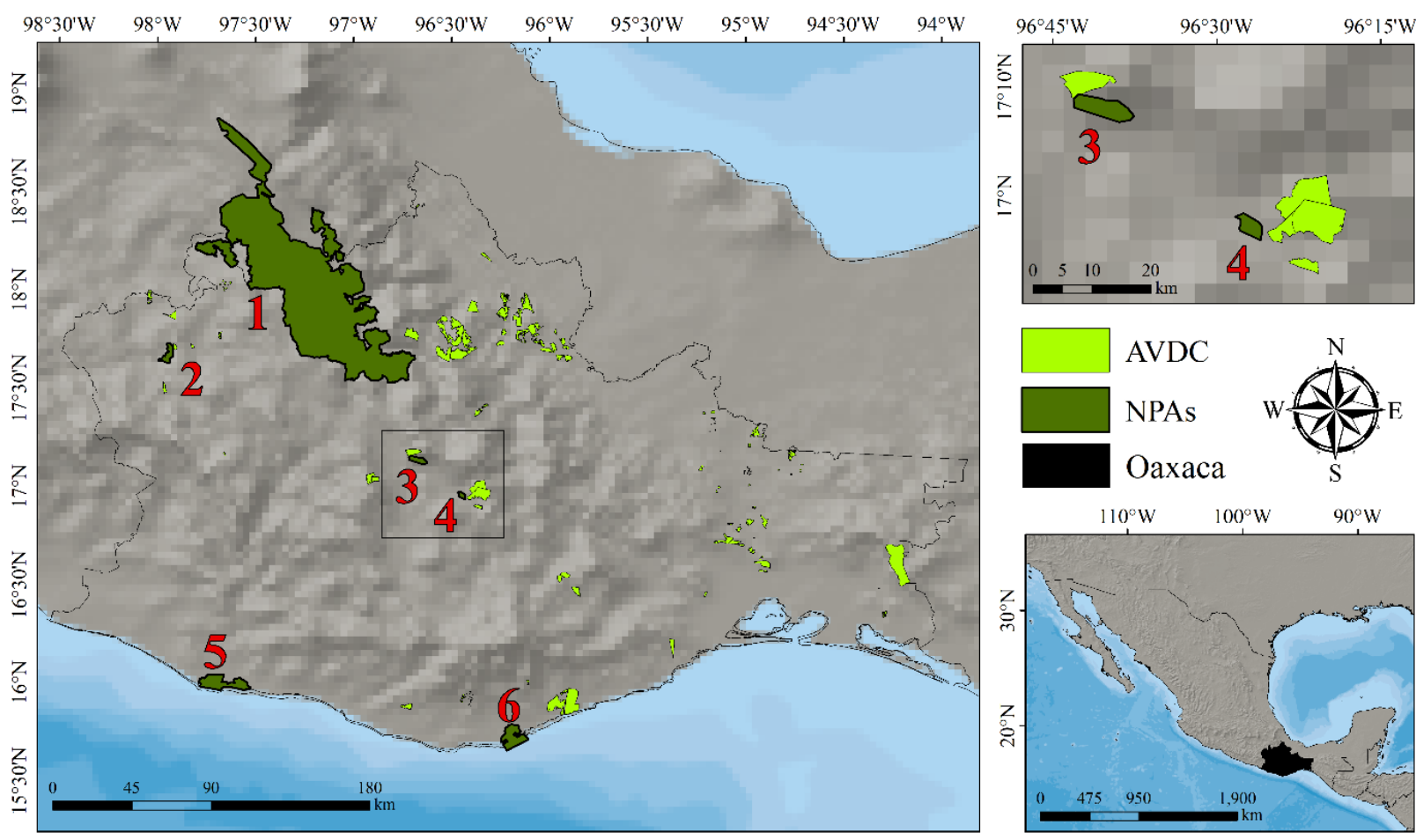

Figure 1. Study area depicting the State of Oaxaca in southern Mexico. The natural protected areas (NPAs, dark green) are: (1) Tehuacán-Cuicatlán Biosphere Reserve, (2) Boquerón de Tonalá Flora and Fauna Protection Area, (3) Benito Juárez National Park, (4) Yagul Natural Monument, (5) Lagunas de Chacahua National Park, (6) Huatulco National Park Areas. The areas voluntarily designated for conservation (AVDC, light green) are landed property (predios) donated for the conservation of biodiversity. 
Table 1. List of variables and ranges, and habitat types included in the multi-criteria inferential analysis and used for the multi-temporal species habitat suitability for jaguar (Panthera onca), puma (Puma concolor), and coyote (Canis latrans). An assessment of significance was assigned to each group of variables and ranges, ranked as not significant (1), little significance (2), neutral (3), significant (4), and very significant (5). The weight values were related to the importance of each group of variables according to the ecology and natural history of jaguar, puma and coyote (see Materials and Methods section for details).

\begin{tabular}{|c|c|c|c|c|c|c|c|}
\hline Variable & Ranges & Jaguar & Puma & Coyote & $\begin{array}{c}\text { Jaguar } \\
\text { Weight } \\
(\%)\end{array}$ & $\begin{array}{c}\text { Puma } \\
\text { Weight } \\
(\%)\end{array}$ & $\begin{array}{c}\text { Coyote } \\
\text { Weight } \\
(\%)\end{array}$ \\
\hline \multirow{12}{*}{$\begin{array}{l}\text { Land use and land cover times series } \\
\text { (INEGI 2009, 2013, and 2016) }\end{array}$} & Urban areas & 1 & 2 & 3 & \multirow{12}{*}{$35 \%$} & \multirow{12}{*}{$35 \%$} & \multirow{12}{*}{$30 \%$} \\
\hline & Agricultural areas & 2 & 3 & 4 & & & \\
\hline & Natural forests & 5 & 5 & 5 & & & \\
\hline & Woods and semi-natural areas & 3 & 4 & 4 & & & \\
\hline & Shrubland & 3 & 4 & 4 & & & \\
\hline & Wetlands & 5 & 3 & 2 & & & \\
\hline & Natural pasture & 3 & 4 & 4 & & & \\
\hline & Permanent cultivated pasture & 2 & 3 & 3 & & & \\
\hline & Low secondary shrub vegetation & 2 & 3 & 4 & & & \\
\hline & Secondary high arboreal vegetation & 4 & 4 & 4 & & & \\
\hline & Without apparent vegetation & 1 & 2 & 2 & & & \\
\hline & Degraded areas & 1 & 2 & 3 & & & \\
\hline \multirow{5}{*}{$\begin{array}{l}\text { Distance from water bodies } \\
\text { (INEGI 2006) }\end{array}$} & $1 \mathrm{~km}$ & 5 & 5 & 5 & \multirow{5}{*}{$11 \%$} & \multirow{5}{*}{$10 \%$} & \multirow{5}{*}{$10 \%$} \\
\hline & $3 \mathrm{~km}$ & 5 & 5 & 5 & & & \\
\hline & $6 \mathrm{~km}$ & 5 & 4 & 4 & & & \\
\hline & $10 \mathrm{~km}$ & 2 & 3 & 3 & & & \\
\hline & $50 \mathrm{~km}$ & 1 & 2 & 2 & & & \\
\hline \multirow{5}{*}{$\begin{array}{l}\text { Inclination } \\
\text { (CONABIO 2016) }\end{array}$} & $<15 \%$ & 5 & 5 & 5 & \multirow{5}{*}{$10 \%$} & \multirow{5}{*}{$13 \%$} & \multirow{5}{*}{$12 \%$} \\
\hline & $15 \%-30 \%$ & 3 & 3 & 3 & & & \\
\hline & $30 \%-45 \%$ & 3 & 3 & 2 & & & \\
\hline & $45 \%-60 \%$ & 2 & 2 & 2 & & & \\
\hline & $>60 \%$ & 1 & 1 & 1 & & & \\
\hline \multirow{6}{*}{$\begin{array}{l}\text { Elevation } \\
\text { (Worldclim 2019) }\end{array}$} & $<500$ masl & 5 & 5 & 5 & \multirow{6}{*}{$11 \%$} & \multirow{6}{*}{$12 \%$} & \multirow{6}{*}{$15 \%$} \\
\hline & 500 - 1000 masl & 5 & 5 & 4 & & & \\
\hline & 1000 - 1500 masl & 4 & 5 & 3 & & & \\
\hline & 1500 - 2000 masl & 3 & 5 & 2 & & & \\
\hline & 2000 - 3000 masl & 2 & 4 & 2 & & & \\
\hline & $>3000$ masl & 1 & 3 & 1 & & & \\
\hline \multirow{3}{*}{$\begin{array}{l}\text { Distances from main roads } \\
\text { (INEGI 2017b) }\end{array}$} & $<1 \mathrm{~km}$ & 1 & 2 & 2 & & & \multirow[b]{3}{*}{$8 \%$} \\
\hline & $1-3 \mathrm{~km}$ & 3 & 3 & 3 & & & \\
\hline & $3-6 \mathrm{~km}$ & 3 & 4 & 4 & $12 \%$ & $10 \%$ & \\
\hline
\end{tabular}




\begin{tabular}{|c|c|c|c|c|c|c|c|}
\hline & $6-10 \mathrm{~km}$ & $\begin{array}{l}4 \\
5\end{array}$ & $\begin{array}{l}4 \\
5\end{array}$ & $\begin{array}{l}4 \\
5\end{array}$ & & & \\
\hline & $>10 \mathrm{~km}$ & 5 & 5 & 5 & & & \\
\hline \multirow{5}{*}{$\begin{array}{l}\text { Distance from human populations } \\
\text { (CONABIO 2014) }\end{array}$} & $1 \mathrm{~km}$ & 1 & 2 & 2 & \multirow{5}{*}{$11 \%$} & \multirow{5}{*}{$10 \%$} & \multirow{5}{*}{$10 \%$} \\
\hline & $3 \mathrm{~km}$ & 2 & 3 & 3 & & & \\
\hline & $6 \mathrm{~km}$ & 3 & 4 & 4 & & & \\
\hline & $10 \mathrm{~km}$ & 4 & 5 & 5 & & & \\
\hline & $50 \mathrm{~km}$ & 5 & 5 & 5 & & & \\
\hline \multirow{5}{*}{$\begin{array}{l}\text { Population Density in Oaxaca } \\
\left.\text { (ind } / \mathrm{km}^{2}\right)\end{array}$} & $1.80-40.53$ & 5 & 5 & 5 & \multirow{5}{*}{$10 \%$} & \multirow{5}{*}{$10 \%$} & \multirow{5}{*}{$15 \%$} \\
\hline & $40.53-136.39$ & 4 & 4 & 4 & & & \\
\hline & $136.39-582.40$ & 3 & 4 & 4 & & & \\
\hline & $582.4-1,784.5$ & 2 & 3 & 3 & & & \\
\hline & $1,784.5-15,506.8$ & 1 & 2 & 2 & & & \\
\hline
\end{tabular}




\section{Indigenous territory and species habitat suitability}

Our initial assumption was that indigenous communities maintain proactive attitudes toward environmental conservation, and hence, higher species habitat suitability for wildlife (Durán et al. 2007). To establish whether such relationship exists between large carnivores' habitat suitability and the indigenous communities, we first determined the selfidentification spatial distribution in Oaxaca. The degree of self-identification for each municipality was based on the "Estimators of the total population and its percentage distribution according to the database of municipalities indigenous self-identification and large age groups", in the Tabulated Data of the INEGI's 2015 Inter-Censal Survey (INEGI 2015). This information was spatially related to the municipalities layer and rasterized using the self-identification value, with a resolution level of $500 \mathrm{~m}^{2}$. Then, this layer was reclassified ranging from $0 \%$ to $40 \%$ as low, $40 \%$ to $60 \%$ as medium, and $>60 \%$ as high indigenous self-identification level, respectively.

Afterward, we recompiled the punctual localities corresponding to these indigenous communities obtained from the INPI-INALI Atlas of indigenous populations belonging to Oaxaca (CARTO 2019) and related them with the corresponding habitat suitability value of jaguar, puma, and coyote for each LULC time series and the corresponding self-identification value using the extraction function of the spatial analysis tool (ArcGis 10.5). After that, a Pearson correlation analysis $(p<0.05)$ was performed between indigenous self-identification and large carnivores' habitat suitability for each LULC time series. The correlation index $(\mathrm{r})$ ranges from -1 to 1 , if $0<r<1$ indicates a positive and direct correlation and if $-1<r<0$ indicates a negative and inverse correlation. Specifically, two analyses were conducted: one with species habitat suitability ranges $>3.0$ and indigenous selfidentification values $>60 \%$, and two with species habitat suitability ranges $>3.0$ and indigenous selfidentification values $>75 \%$. These indigenous selfidentification values were set at $60 \%$ and $75 \%$, since we were interested in determining the municipalities with a preponderance of indigenous self-identification communities; that is, where $>60 \%$ of the communi- ties regarded themselves as indigenous.

These values enabled a better visualization of each scenario of LULC for the correlations between species habitat suitability and indigenous self-identification. If the correlation was positive, we expected points occurrences with a high degree of indigenous communities' self-identification and a high species habitat suitability. These were areas with high potential for conservation. If the relation was negative, we expected no geographical concordance between indigenous communities' self-identification and species habitat suitability. Under this scenario, it is likely that other factors existed (environmental, social or economic) affecting indigenous communities' self-identification and/or species habitat suitability. Likewise, correlations were identified between the areas of medium and high species habitat suitability with the current geo-economic regions of Oaxaca (Istmo, Papaloapan, Cañada, Sierra Norte, Valles Centrales, Sierra Madre del Sur, Sierra Mixteca, and Costa) (Irazoque and Barbosa 1962). For this purpose, we performed a density analysis using correlation graphs for visualizing changes affecting species habitat suitability in the Zapotec and Mixtec territories, using the R Studio platform version 3.5.3 (R Core Team 2015).

Finally, we compared areas of species habitat suitability models, with jaguar, puma, and coyote records in natural protected areas (NPAs) and areas voluntarily designated for conservation (AVDC), between 2000 and 2019 (Table 2). The aim was to analyze whether the species habitat suitability models matched the large carnivores' occurrences (these occurrences were not used to estimate the habitat suitability models for each species). These records were searched from commonly used sources as GBIF Backbone Taxonomy (https://doi.org/10. 15468/39omei), SNIB (http://enciclovida.mx), VertNet (http://portal.vertnet.org/search), the digitized Collection of Biological Photo-Specimens (Colección de Fotocolectas Biológicas, http:// ibdata.ib.unam.mx/web/colecciones.php) of the Institute of Biology UNAM, and the database of Biological Monitoring of the Protected Natural Areas of the CONANP (https://simec.conanp. gob.mx/monitoreo.php). This process was conducted using the $\mathrm{R}$ Studio platform version 3.5.3 (R Core Team 2015). 
Table 2. Number of occurrence records from 2000 to 2018 for jaguar, puma, and coyote in natural protected areas (NPAs) and areas voluntarily designated for conservation (AVDC) in Oaxaca, Mexico.

\begin{tabular}{|c|c|c|c|c|}
\hline $\begin{array}{c}\text { Conservation } \\
\text { areas }\end{array}$ & Name of NPAs and AVDC & Species & $\begin{array}{l}\text { Number of } \\
\text { records }\end{array}$ & Year \\
\hline \multirow{30}{*}{ NPAs } & \multirow{16}{*}{ Tehuacán-Cuicatlán Biosphere Reserve } & \multirow{8}{*}{ Puma } & 4 & 2004 \\
\hline & & & 1 & 2005 \\
\hline & & & 5 & 2007 \\
\hline & & & 3 & 2008 \\
\hline & & & 12 & 2010 \\
\hline & & & 6 & 2011 \\
\hline & & & 10 & 2012 \\
\hline & & & 7 & 2013 \\
\hline & & \multirow{8}{*}{ Coyote } & 10 & 2003 \\
\hline & & & 13 & 2004 \\
\hline & & & 5 & 2005 \\
\hline & & & 2 & 2007 \\
\hline & & & 1 & 2010 \\
\hline & & & 7 & 2011 \\
\hline & & & 11 & 2012 \\
\hline & & & 6 & 2013 \\
\hline & \multirow{6}{*}{$\begin{array}{l}\text { Boquerón de Tonalá Flora and } \\
\text { Fauna Protection Area }\end{array}$} & \multirow{4}{*}{ Puma } & 50 & 2012 \\
\hline & & & 16 & 2013 \\
\hline & & & 9 & 2014 \\
\hline & & & 5 & 2015 \\
\hline & & Covote & 1 & 2013 \\
\hline & & & 3 & 2014 \\
\hline & \multirow{3}{*}{ Benito Juárez National Park } & Puma & 1 & 2014 \\
\hline & & & 1 & 2015 \\
\hline & & Coyote & 1 & 2014 \\
\hline & Huatulco National Park & Coyote & 1 & 2018 \\
\hline & & & 1 & 2012 \\
\hline & & & 4 & 2014 \\
\hline & Yagul Natural Monument & Coyote & 25 & 2015 \\
\hline & & & 2 & 2016 \\
\hline \multirow{20}{*}{ AVDC } & Barranca del Epazote & Coyote & 1 & 2014 \\
\hline & \multirow{3}{*}{ Camino a la Calavera } & Jaguar & 1 & 2012 \\
\hline & & Puma & 2 & 2012 \\
\hline & & Coyote & 2 & 2012 \\
\hline & Corral de Piedra & Coyote & 1 & 2015 \\
\hline & El Baño & Puma & 7 & 2013 \\
\hline & \multirow{3}{*}{ El Huerto } & \multirow{3}{*}{ Puma } & 2 & 2012 \\
\hline & & & 4 & 2013 \\
\hline & & & 1 & 2014 \\
\hline & \multirow{2}{*}{ El paredón } & Puma & 5 & 2016 \\
\hline & & Coyote & 5 & 2016 \\
\hline & \multirow{5}{*}{ El Pie de la Peña } & \multirow{3}{*}{ Puma } & 1 & 2013 \\
\hline & & & 5 & 2014 \\
\hline & & & 1 & 2015 \\
\hline & & \multirow{2}{*}{ Coyote } & 1 & 2013 \\
\hline & & & 1 & 2014 \\
\hline & El Portillo & Coyote & 7 & 2013 \\
\hline & El Sauz 1 & Puma & 1 & 2012 \\
\hline & El Sauz 2 & Puma & 5 & 2012 \\
\hline & El Tular & Coyote & $\begin{array}{l}1 \\
2\end{array}$ & $\begin{array}{l}2014 \\
2015\end{array}$ \\
\hline
\end{tabular}




\begin{tabular}{|c|c|c|c|c|}
\hline & Hermenegildo & Coyote & 5 & 2016 \\
\hline & \multirow{7}{*}{ La 2000} & \multirow{4}{*}{ Puma } & 2 & 2013 \\
\hline & & & 4 & 2014 \\
\hline & & & 3 & 2015 \\
\hline & & & 3 & 2016 \\
\hline & & \multirow{3}{*}{ Coyote } & 2 & 2013 \\
\hline & & & 1 & 2014 \\
\hline & & & 5 & 2016 \\
\hline & \multirow{2}{*}{ La Cañada de Gregorio } & \multirow{2}{*}{ Puma } & 1 & 2015 \\
\hline & & & 11 & 2016 \\
\hline & \multirow{2}{*}{ La Cruz } & \multirow{2}{*}{ Puma } & 4 & 2014 \\
\hline & & & 3 & 2015 \\
\hline & \multirow{2}{*}{ La Cuevita } & \multirow{2}{*}{ Puma } & 2 & 2014 \\
\hline & & & 1 & 2015 \\
\hline & La Peña del Corral & Puma & 6 & 2015 \\
\hline & La Rosa de Gacha & Coyote & 9 & 2013 \\
\hline & La Ventana & Puma & 2 & 2014 \\
\hline & Las Cuevas & Puma & 1 & 2014 \\
\hline & Los Cajetes & Coyote & 3 & 2015 \\
\hline & Los Lavaderos & Puma & 1 & 2012 \\
\hline & Los Tepetates & Puma & 1 & 2014 \\
\hline & \multirow{4}{*}{ Mogote del Pozo } & \multirow{3}{*}{ Puma } & 18 & 2014 \\
\hline & & & 1 & 2015 \\
\hline & & & 19 & 2016 \\
\hline & & Coyote & 5 & 2016 \\
\hline \multirow[t]{28}{*}{ AVDC } & \multirow{3}{*}{ Paredones 2} & \multirow{2}{*}{ Puma } & 2 & 2013 \\
\hline & & & 11 & 2014 \\
\hline & & Coyote & 1 & 2014 \\
\hline & Río Concha & Coyote & 2 & 2013 \\
\hline & Río del Jaguar & Jaguar & 1 & 2013 \\
\hline & Río del Jaguar 2 & Puma & 1 & 2015 \\
\hline & \multirow{3}{*}{ Río Vaquero } & \multirow{2}{*}{ Puma } & 1 & 2014 \\
\hline & & & 2 & 2015 \\
\hline & & Coyote & 1 & 2014 \\
\hline & \multirow{2}{*}{ La Lima } & \multirow{2}{*}{ Jaguar } & 2 & 2014 \\
\hline & & & 3 & 2015 \\
\hline & La Manzanita & Jaguar & 3 & 2014 \\
\hline & Xhachue & Jaguar & 1 & 2015 \\
\hline & Arroyo del Aguacatal & Puma & 5 & 2014 \\
\hline & Camino a Yelagago & Puma & 3 & 2015 \\
\hline & Camino de Conducción de Agua Potable & Puma & 2 & 2015 \\
\hline & Guia Dhao & Puma & 1 & 2015 \\
\hline & La Lima & Puma & 1 & 2014 \\
\hline & \multirow{2}{*}{ La Manzanita } & Puma & 1 & 2014 \\
\hline & & & 1 & 2015 \\
\hline & Nhiza Yoya & Puma & 1 & 2015 \\
\hline & Piedra Flor 2 & Puma & 2 & 2014 \\
\hline & Pozo del Aguacatal & Puma & 3 & 2014 \\
\hline & & & 1 & 2015 \\
\hline & Río de la Palma & Puma & 2 & 2014 \\
\hline & Roa Gulabexho & Puma & 1 & 2015 \\
\hline & Xhachue & Puma & 1 & 2015 \\
\hline & Rancho Cajón & Coyote & 1 & 2014 \\
\hline
\end{tabular}




\section{RESULTS}

\section{Multi-temporal analysis of species habi- tat suitability}

In general, the suitable habitats (medium and high) for the three large carnivore species consisted mainly of areas covering natural and semi-natural forest, as well as secondary vegetation, wetlands and natural shrubland. Likewise, these areas included water bodies in the vicinity and showed a low or medium anthropic and agricultural and livestock impact (Figure 2). For the jaguar, there were fewer areas with a medium and high habitat suitability values than for the puma and coyote, respectively. These areas were found mainly in eastern and southern Oaxaca, and to a lesser extent in northern and western portions of the State. The areas of low habitat suitability included larger villages or towns and main cities, and areas crossed by major roads and highways (Figure $2)$.

With respect to the three time periods, the high habitat suitability areas showed a decrease for jaguar and coyote from LULC 2009 to LULC 2013, but an increase from LULC 2013 to LULC 2016. For example, high habitat suitability areas decreased $0.28 \%$ for coyote and $3.21 \%$ for jaguar from 2009 to 2013 and increased $0.93 \%$ for coyote and $6.51 \%$ for jaguar from 2013 to 2016. In contrast, for puma, high habitat suitability areas decreased $0.30 \%$ from 2009 to 2013, and $0.77 \%$ from 2013 to 2016 . These high suitability differences between species may result from high elevational habitat preferences of puma ( $>1500$ masl; Table 1) compared to low and medium elevation habitat preferences of coyote and jaguar (Figure 2).

We observed a high number of records of the puma (130 and 159) and coyote (93 and 55) in both NPAs and AVDC, respectively. For example, the TehuacánCuicatlán Biosphere Reserve, the Boquerón de Tonalá Flora and Fauna Protection Area, the Yagul Natural Monument, and the Benito Juárez National Park ranked top in the number of records, as well as some AVDC (Table 2). Only 11 records of jaguars were observed for AVDC, and no records were observed for NPAs. These conservation areas showed a mediumto-high habitat suitability for the three large carnivore species (Figure 2; Add file 1, 2, 3). However, the Boquerón de Tonalá Flora and Fauna Protection Area, the Yagul Natural Monument and the Benito Juárez National Park showed low-to-medium habitat suitability areas for these species (Figures 1 and 2).

\section{Indigenous territories and species habi- tat suitability}

The areas of higher overlap between indigenous territories and species habitat suitability were found in western, southern, and eastern portions of Oaxaca. These areas included local inhabitants that described themselves as indigenous communities, with self-identification values of over $60 \%$ (Figure 3 ). The high rates of indigenous self-identification and high values of species suitability models overlapped in six of the eight geo-economic regions of Oaxaca: Sierra Norte, southeastern and western parts of the Sierra Sur, the Coastal Region, and some municipalities of the Mixtec region (Figures 2 and 3).

The correlation analyses comparing $>60 \%$ of species habitat suitability with indigenous communities' self-identification showed the following trends (Figure 4A). The Zapotec areas showed a significant positive correlation with medium-to-high habitat suitability values ( $\mathrm{CI}=95 \%$ for all correlations) for jaguar (LULC 2009, $\mathrm{r}=0.063$; LULC 2013, $\mathrm{r}=0.099 ;$ LULC $2016, \mathrm{r}=0.108, p<0.05$ ), and puma (LULC 2009, $\mathrm{r}=0.058$; LULC 2013, $\mathrm{r}=0.097$; LULC 2016, $\mathrm{r}=$ $0.107, p<0.05)$. For coyote, a negative significant correlation was observed (LULC 2009, $\mathrm{r}=-0.177$; LULC 2013, $\mathrm{r}=-0.166$; LULC 2016, $\mathrm{r}=-0.201$, $p<0.05)$. The Mixtec territories showed a negative significant correlation with the coyote (LULC 2009, $\mathrm{r}=-0.210$; LULC 2013, $\mathrm{r}=-0.188$; LULC 2016, $\mathrm{r}$ $=-0.205, p<0.05$ ), but not with the puma (LULC 2009, $\mathrm{r}=-0.386$; LULC 2013, $\mathrm{r}=-0.028$; LULC 2016, $\mathrm{r}=-0.019, p>0.1$ ), nor the jaguar (LULC 2009, $\mathrm{r}=$ 0.003; LULC 2013, $\mathrm{r}=0.013$; LULC 2016, $\mathrm{r}=0.017$, $p>0.1$ ) (Figure 4A).

Moreover, the correlation analyses comparing the species habitat suitability values $>75 \%$ with indigenous communities' self-identification showed a more pronounced trend (Figure 4B). The Zapotec territories showed a significant positive correlation with the puma and a significant negative correlation with coyote $(p<0.05)$. The Mixtec areas showed a significant negative correlation with the coyote, and a negative tendency for the puma. For the jaguar, the Mixtec self-identification showed a positive tendency (except for 2013) and a significant positive correlation with Zapotec communities in the LULC $2009(p<0.05)$, LULC $2013(p<0.05)$ and LULC $2016(p<0.05)$, respectively (Figure 4).

\section{DISCUSSION}

The perceptions and the cultural heritage of indigenous communities are key components to establish strategies for ecosystem and biodiversity conservation, including these large carnivore species. In 
Meso-American indigenous cultures, for instance, the jaguar plays an important role within their communities cosmovision (Saunders 1994; Seller 2004; Sahagún 2005; López Austin 2012; Olivier 2016; Sugiyama 2016). Thus, according to their inclination and perceptions, this cosmovision may have important implications for ecosystems and resources maintenance in the long-term (Conforti and de Azevedo 2003; Treves and Karanth 2003; Campbell and Torres Alvarado 2011; Fita 2018). This is the result of nature ancestral perception and the large carnivore species awareness, referred as their "bio-cultural memory" (Toledo and Barrera 2008). For example, in Zapotec culture, jaguar, puma, and coyote are present in their common language (Seller 2004) and there are jaguar and puma clay figures representation from Monte Albán (i.e. a pre-Columbian archaeological site) (López Austin 2013). There are also stories and legends about the Zapotec origins involving the jaguar as an animal associated with gods, stories that remain until today (Henestrosa 2003). In Mixtec culture, the jaguar and coyote are represented in the Nutall Codex as an important species for their history and cosmovision (Zouche-Nutall 1987; Seller 2004).

The close and long-standing interactions of Mesoamerican indigenous communities with these large carnivore species have been gradually changing over time, because of the European influence (i.e. perceptions and land used dynamics) brought to America (Seller 2004; López-Austin 2013; Sánchez and Durán 2018). This result in some changes of the indigenous collective imaginary that generates a distortion towards a more utilitarian vision of natural resources, as seen in part of our results, in terms of communities' self-identification distribution and habitat suitability trends, so directly impacting the ecosystems where these large carnivores occur. This emphasizes the importance of empowering the collective and bio-cultural memory of these indigenous communities with the ecosystems and biodiversity conservation, which in turn play an important role for the environmental services availability and well-being of local
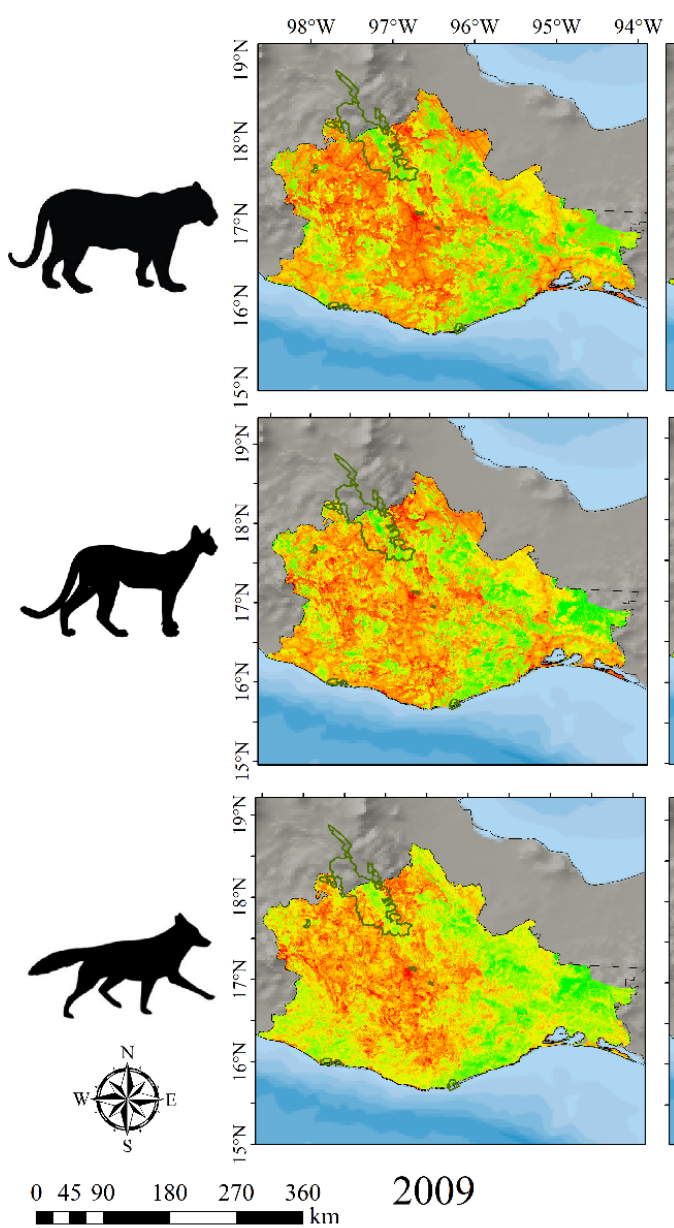

2009
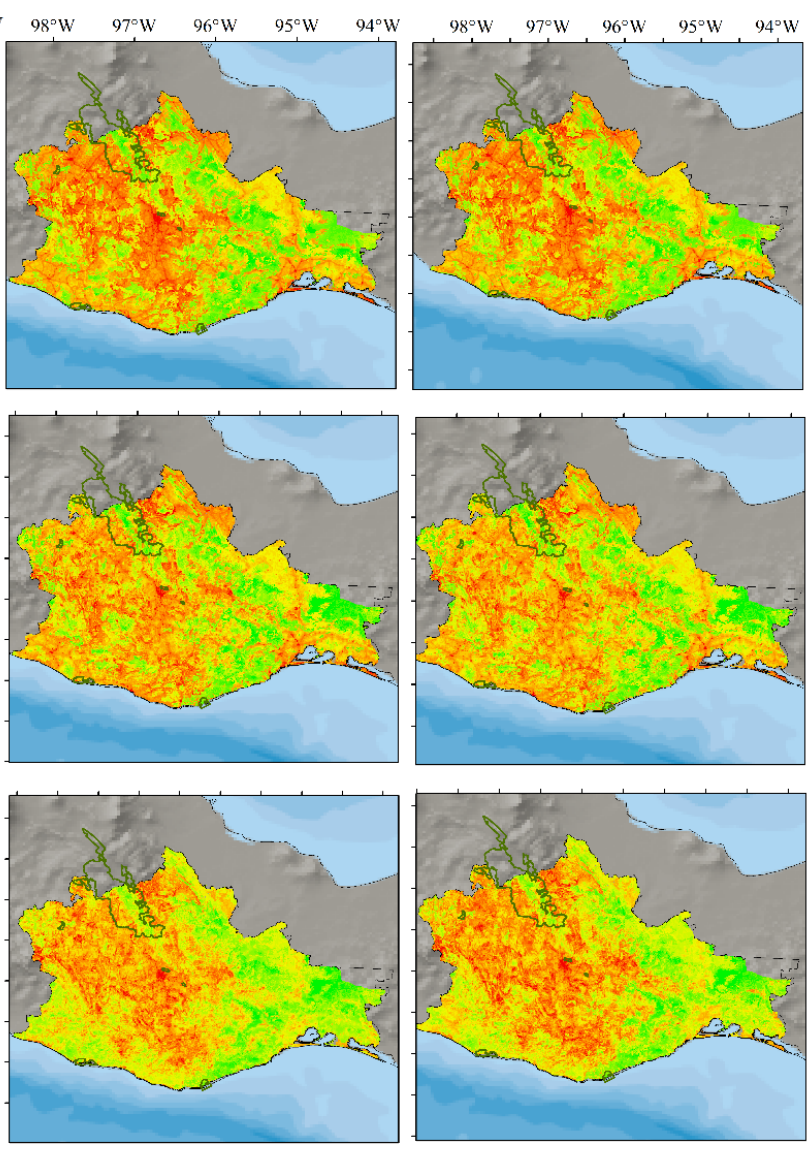

2013

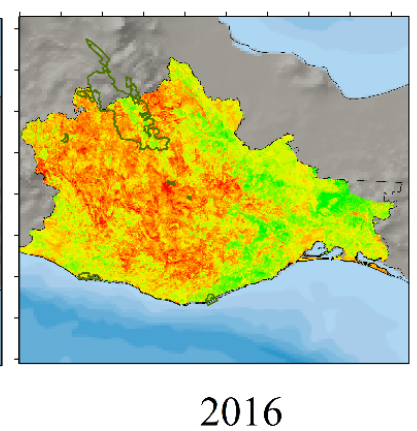

Figure 2. Distribution of high (green), medium (yellow), and low (red) habitat suitability for jaguar, puma, and coyote, in the INEGI land use and land cover map of LULC 2009, LULC 2013, and LULC 2016 of Oaxaca, respectively. 
Guerrero-Montes de Oca et al. 2021. Connecting worlds: indigenous territories, habitat suitability and conservation of three large carnivores (Mammalia: Carnivora) in southern Mexico
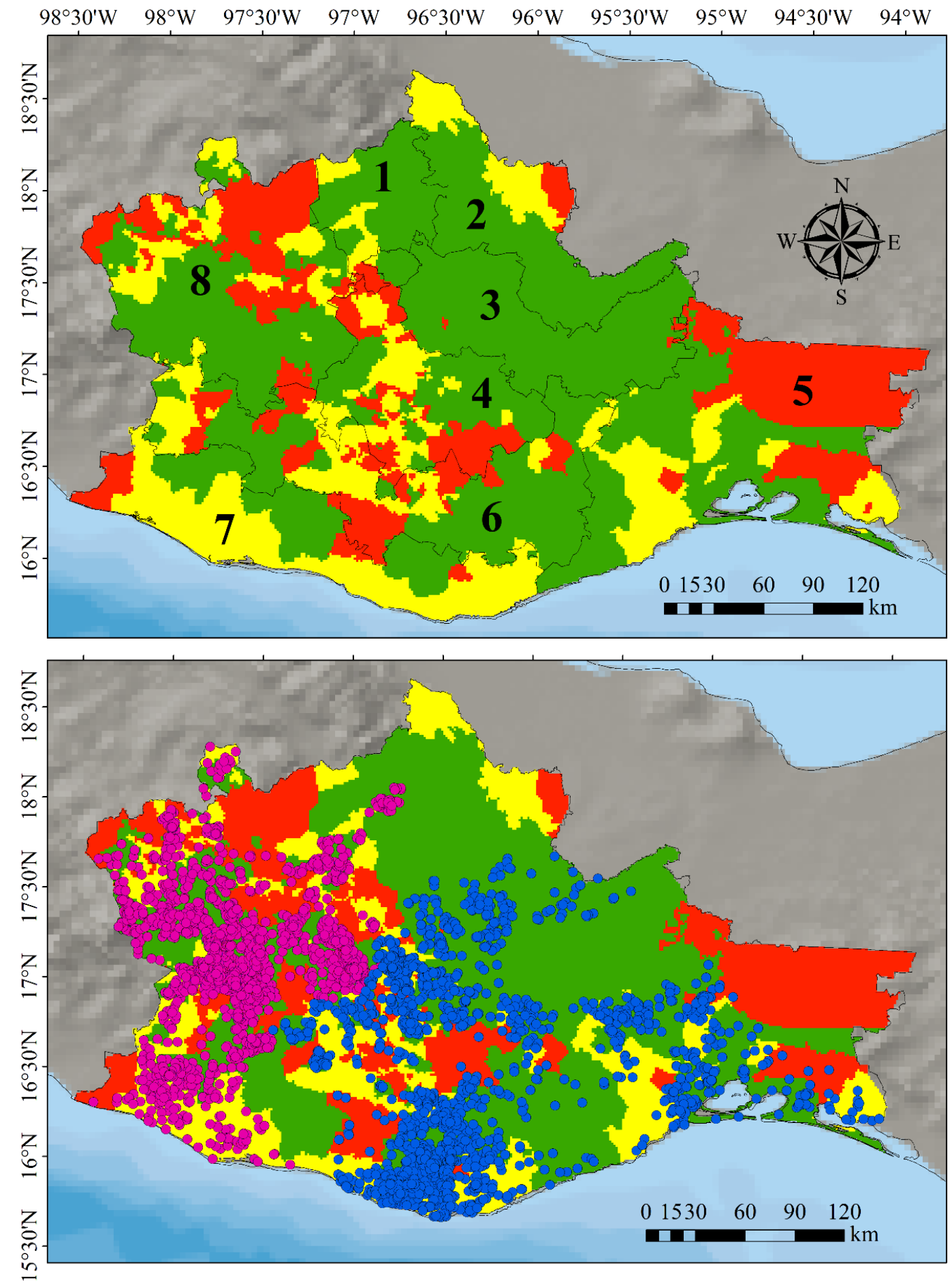

Figure 3. Spatial distribution of high (green), medium (yellow), and low (red) indigenous self-identification communities by geo-economic regions (top panel), and by indigenous Zapotec (blue points) and Mixtec (magenta points) villages (bottom panel). The geo-economic regions are: Cañada (1), Papaloapan (2), Sierra Norte (3), Valles Centrales (4), Istmo (5), Sierra Sur (6), Costa (7), and Mixteca (8).

indigenous communities (Buenrostro-Silva et al. 2015; Espinoza-Ramírez et al. 2017).

Our study also documented an important influ- ence of the Zapotec and Mixtec indigenous communities on the ecosystems maintenance to support the populations of these large carnivore species in the 
A
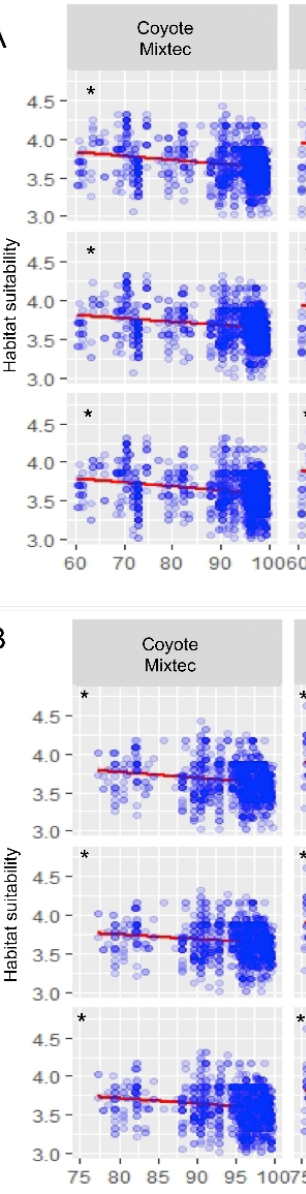
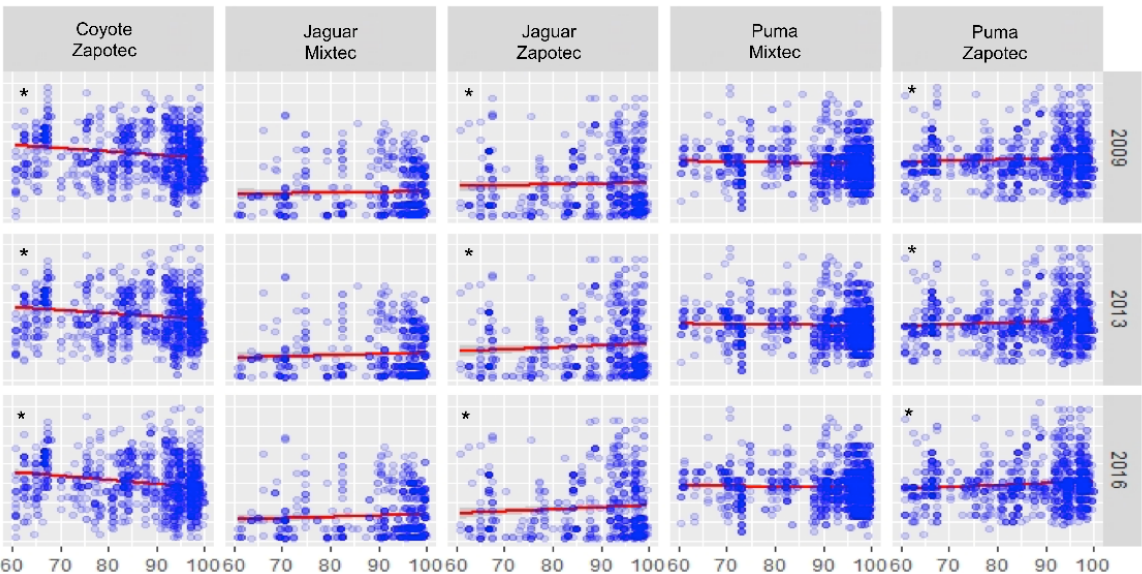

Self-identification $(\%)$
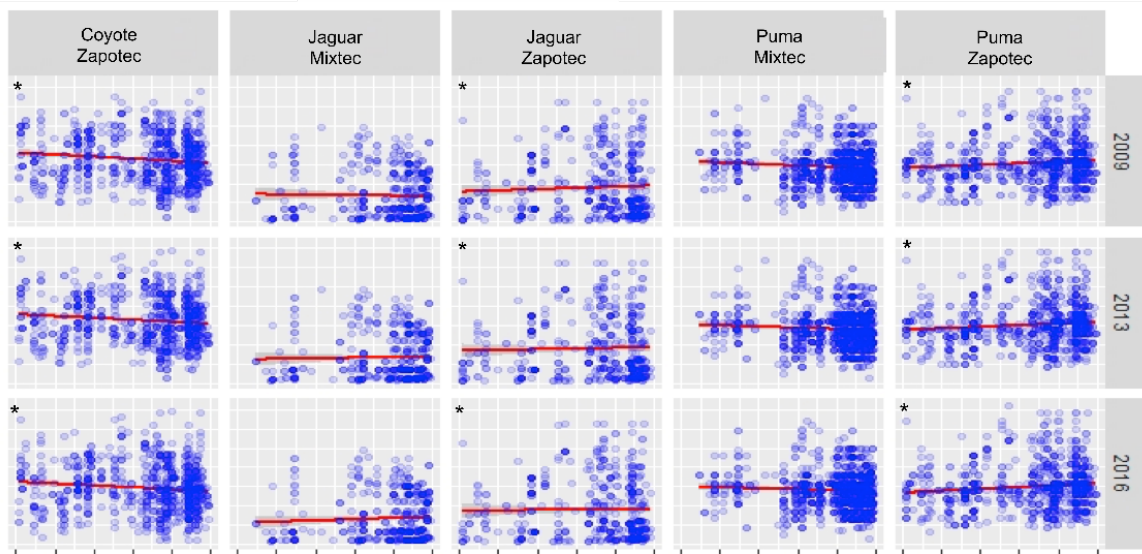

Self-identification $(\%)$

Figure 4. Pearson correlation ranks between jaguar, puma, and coyote habitat suitability $(>3.0)$ and areas holding indigenous self-identification communities. Indigenous self-identification with $>60 \%(\mathrm{~A})$, and $>$ $75 \%$ (B) are depicted for the Zapotec and Mixtec communities, respectively. Correlations are indicated for the LULC 2009 (upper panel), LULC 2013 (central panel), and LULC 2016 (bottom panel) time periods, respectively. ${ }^{*}$ Significant correlation $(p<0.05)$.

long-term. We showed that the areas with mediumto-high species habitat suitability overlapped meanly with the Zapotec territories and to a lesser extent with Mixtec territories. Despite no positive correlation was observed for the coyote, it is likely that coyotes also actually occur in these areas as well (Botello et al. 2008). These areas should be prioritized for the conservation of these large carnivore species, given the proactive attitude of these indigenous communities toward nature. However, it is possible, that the potential of these large carnivore species as key top predator has been largely overlooked (Sanderson et al. 2002; Hunter 2005; Ray 2005; Granados-Peña et al. 2014). Additionally, coyotes did not show a positive correlation in areas of Zapotec and Mixtec high self-identification, possibly due to their high ecological plasticity and adaptability to disperse into anthropized habitats, as urban and peri-urban areas (Hidalgo-Mihart et al. 2004; Gehrt and Riley 2010;
Hody et al. 2019). Moreover, some areas outside the NPAs and AVDCs showed high ecosystem degradation due to external factors of these indigenous communities (e.g., extensive expansion of the agricultural and livestock, development of infrastructure, human demographic growth), that negatively affect this correlation result, but shows a real perspective about biodiversity conservation of the region (Botello et al. 2008; Buenrostro-Silva et al. 2015).

We observed that six of the eight geo-economic regions in Oaxaca included areas with high species habitat suitability that coincided with the highest values of indigenous self-identification. Nonetheless, not all the AVDC areas show medium-high habitat suitability values for these large carnivore species in the region. The AVDC areas with low-medium habitat suitability values were highly degraded until they were incorporated recently into governmental conservation programs in 2008 (LGEEPA 2008). It is likely that 
some of these AVDC areas should need more time to reach a medium or high suitable habitat recover (Monroy et al. 2019). Thus, it is necessary to include additional areas or corridors of high suitable habitats for these species overlapping with areas holding a high indigenous self-identification to ensure the conservation of these ecosystems in the long term. For example, additional areas and corridors with high suitable habitats could be connected with large protected areas as the Tehuacán-Cuicatlán Biosphere Reserve, the Huatulco National Park, the Lagunas de Chacahua National Park, the Benito Juárez National Park, and small protected areas as Yagul Natural Monument, Playa Escobilla Sanctuary, Playa de la Bahía de Chacahua Sanctuary and Boquerón de Tonalá Flora and Fauna Protection Area (Monroy-Gamboa et al. 2015, 2019; Wilson et al. 2011).

It is important to involve the indigenous communities in the environmental conservation planning and actions in local and regional resolution processes, since $40 \%$ of the priority terrestrial regions of Oaxaca belong to indigenous territories (Boege 2008). Oaxaca holds a high diversity of conservation initiatives, including areas of payments for biodiversity conservation and ecosystem services, voluntary areas for conservation, and forestry management, which have been recognize at international level as successful examples of local community participation in conservation efforts (Monroy-Gamboa et al. 2015, 2019). For example, there are over one hundred conservation areas that have been voluntarily proposed by local communities such as the Unión de Comunidades Zapotecas-Chinantecas located north of Oaxaca, and the Sistema Comunitario para la Biodiversidad in the coast that have established very successful conservation programs protecting biodiversity hotspots (Monroy-Gamboa et al. 2015, 2019). In addition, some governmental agencies as the National Commission of Forestry have established reforestation areas (CONAFOR 2010). There are also programs of payment for conserving areas for their importance to biodiversity and provision of environmental services (Martin et al. 2011).

This scenario, in turns, may generate not only a higher economic independence by developing activities contributing to biodiversity conservation as their main objective, but also could support and adjust other activities to decrease negative environmental impacts (e.g., deforestation, expansion of agriculture and livestock, etc.). In all this process considering these large carnivore species as important pieces not only for the ecosystem and ecological processes conservation, but also for the protection and safeguarding of the ancient cosmovision of local communities. When a specie is appreciated and regarded as a symbol of nature, a proactive attitude permeates the ar- eas where indigenous communities and these carnivore species coexist (Mech 1970; Toledo and BarreraBassols 2008) (Figures 1-4). Therefore, a sustainable use of natural resources and the proportion of habitat connectivity with other conservation areas actively fostered by the indigenous communities could establish an integrated regional strategy of biodiversity conservation. This strategy should involve indigenous communities, stakeholders, and federal and local governmental and non-governmental organizations (Gadgil et al. 1993; Conforti and de Azevedo 2003) in order to generate a change in the negative perception towards these carnivore species, turning them as beneficial rather than threatening species (Millar et al. 2016) and then achieve a peaceful coexistence in all these territories.

\section{CONCLUSION}

Our study assessed species habitat suitability of the jaguar $(P$. onca), puma $(P$. concolor $)$, and coyote (C. latrans), and quantified the overlap with the Mixtec and Zapotec indigenous territories in a biodiversity hotspot in southern Mexico. We found a positive and proactive relationship between indigenous communities' self-identification and a high species habitat suitability for the conservation of these large carnivores in the Sierra Norte, Sierra Sur, Coastal, and Mixtec regions. Given that most of these areas occur outside natural protected areas, the inclusion of indigenous communities in the management and planning of their territory is crucial for preserving their ethnocentric vision, and ensuring the conservation of these charismatic large carnivores and their habitat. The long-term conservation of ecosystems and their provision of environmental services will ultimately benefit the well-being of the indigenous communities in this biodiversity hotspot.

\section{ACKNOWLEDGEMENT}

This paper constitutes a partial fulfillment of the Graduate, Master Degree Program in Biological Sciences of the Universidad Nacional Autónoma de México (UNAM) of the first author. EG-M thanks the Posgrado en Ciencias Biológicas, the Instituto de Biología-UNAM and the scholarship and financial support provided by the Consejo Nacional de Ciencia y Tecnología (CONACyT) (scholarship 854974). We owe special thanks to Mr. Chris Follett for his effort in translation and edition of this script. We also thank the reviewers for their comments, which helped to improve the manuscript. 


\section{DATA AVAILABILITY}

The data used to support the findings of this study are available from the corresponding author upon reasonable request.

\section{CONFLICT OF INTEREST}

The authors have no conflicts of interest to declare.

\section{CONTRIBUTION STATEMENT}

Conceived of the presented idea: EG-M, AA-A. Carried out the experiment: EG-M, CGH, FMF, AA-A. Carried out the data analysis: EG-M, AA-A. Wrote the first draft of the manuscript: EG-M, AA-A, FB, VS-C. Review and final write of the manuscript: EGM, FB, VS-C, AA-A. Supervision: FB, VS-C, AA-A.

\section{REFERENCES}

Bartolomé MA, Barabas AM (2008) El pueblo ñu savi: los mixtecos. Arqueología mexicana 15:68-73

Beier P, Majka D, Jenness J (2007) Conceptual steps for designing wildlife corridors. Corridor Design, Arizona, USA

Benítez A, Finegan B, Jones J, Casanoves F, González-Maya JF (2013) Aproximación al hábitat potencial para jaguar (Panthera onca) en la región Caribe colombiana. In: Payán Garrido E, Castaño-Uribe C (eds) Grandes felinos de Colombia. Vol. I. Panthera. Fundación Herencia Ambiental Caribe, Conservación Internacional \& Cat Specialist Group UICN/SSC, Bogotá, pp. 175-182

Boege, E (2008) El patrimonio biocultural de los pueblos indígenas de México: hacia la conservación in situ de la biodiversidad y agrodiversidad en los territorios indígenas. Instituto Nacional de Antropología e Historia // Comisión Nacional para el Desarrollo de los Pueblos Indígenas, Mexico City, Mexico

Botello, F, Sánchez-Cordero V, González G (2008) Diversidad de carnívoros en Santa Catarina Ixtepeji, Sierra Madre de Oaxaca, México. In: Lorenzo C, Espinoza E, Ortega J (eds) Avances en el estudio de los mamíferos de México II. Asociación Mexicana de Mastozoología, Mexico City, pp. 335-354

Brooks, TM, Mittermeier RA, da Fonseca GA, Gerlach J, Hoffmann M, Lamoreux JF, Mittermeier CG, Pilgrim JD, Rodrigues AS (2006) Global biodiversity conservation priorities. Science 313:58-61
Buenrostro-Silva A, Pérez DS, García-Grajales J (2015) Mamíferos carnívoros del parque Nacional Lagunas de Chacahua, Oaxaca, México: Riqueza, abundancia y patrones de actividad. Revista Mexicana de Mastozoología (Nueva Época) 5:39-54

Carabias J, Sarukhán J, de la Maza J, Galindo C (2010) Patrimonio natural de México. Cien casos de éxito. Comisión Nacional para el Conocimiento y Uso de la Biodiversidad, Mexico City, Mexico

CARTO (2019) Unlock the power of spatial analysis. https://carto.com Accessed 19 August 2019

Campbell MON, Torres Alvarado, ME (2011) Public perceptions of jaguars Panthera onca, pumas Puma concolor and coyotes Canis latrans in El Salvador. Area, 43:250-256

Clark JD, Dunn JE, Smith KG (1993) A multivariate model of female black bear habitat use for a Geographic Information System. Journal of Wildlife Management, 57:519-526

CONABIO (2014) Tipología municipal por asentamiento humano, escala 1:250 000. Comisión Nacional para el Conocimiento y Uso de la Biodiversidad. Ciudad de México, México

CONABIO (2016) Pendiente, escala: 1:4000000 by Guevara M and Arroyo-Cruz CE. Comisión Nacional para el Conocimiento y Uso de la Biodiversidad. Ciudad de México, México.

CONAFOR (2010) Servicios ambientales y cambio climático. Coordinación General de Producción y Productividad. Comisión Nacional Forestal. Zapopan, Jalisco, México

Conforti VA, de Azevedo FCC (2003) Local perceptions of jaguars (Panthera onca) and pumas (Puma concolor) in the Iguaçu National Park area, south Brazil. Biological conservation 111:215-221

Crooks KR (2002) Relative Sensitivities of Mammalian Carnivores to Habitat Fragmentation. Conservation Biology 16:488-502

Crooks KR, Burdett CL, Theobald DM, King SR, Di Marco M, Rondinini C, Boitani L (2017) Quantification of habitat fragmentation reveals extinction risk in terrestrial mammals. Proceedings of the National Academy of Sciences 114:7635-7640

Descola P (2001) Construyendo naturalezas. Ecología simbólica y práctica social. In: Descola P, Gísli P (eds) Naturaleza y sociedad: Perspectivas antropológicas. Siglo Veintiuno Editores, Mex- 
Guerrero-Montes de Oca et al. 2021. Connecting worlds: indigenous territories, habitat suitability and conservation of three large carnivores (Mammalia: Carnivora) in southern Mexico

Ethnobio Conserv 10:26

ico City, pp. 101-121

Dirección General de Población de Oaxaca (2018) Oaxaca población Siglo XXI: Población indígena http://www.digepo.oaxaca.gob.mx/ recursos/revistas/revista42.pdf Accessed 3 September 2019

Durán E, Mas JF, Velázquez A (2007) Cambios en las coberturas de vegetación y usos del suelo en regiones con manejo forestal comunitario y áreas naturales protegidas de México. In: Bray DB, Merino-Pérez L, Barry D (eds) Los Bosques Comunitarios de México. Manejo Sustentable de Paisajes Forestales. Instituto Nacional de Ecología, Mexico City, pp. 267-302

Easter T, Bouley P, Carter N (2020) Intraguild dynamics of understudied carnivores in a humanaltered landscape. Ecology and Evolution 10:54765488

Ellis EC (2011) Anthropogenic transformation of the terrestrial biosphere. Philosophical Transactions of the Royal Society A: Mathematical, Physical, and Engineering Sciences 369:1010-1035

Espinoza-Ramírez MK, Luna-Krauletz MD, AlfonsoCorrado C, Clark-Tapia R (2017) Registros recientes de felinos en el bosque de niebla en Santiago Comaltepec, Sierra Norte de Oaxaca, México. Acta zoológica mexicana 33:398-401

ESRI (2011) ArcGIS Desktop: Release 10.5.1. Environmental Systems Research Institute, Redlands, $\mathrm{CA}$

FAO (2017) The future of food and agriculture: Trends and challenges. Annual Report. Food and Agriculture Organization of the United Nations. Rome

Gadgil M, Berkes F, and Folke C (1993) Indigenous knowledge for biodiversity conservation. Ambio 22:151-156

Galindo C (2010) Áreas comunitarias protegidas en Oaxaca. In: Carabias J, Sarukhán J, de la Maza J, Galindo C (eds) Patrimonio natural de México. Cien casos de éxito. Comisión Nacional para el Conocimiento y Uso de la Biodiversidad, Mexico City, pp. $20-21$

García-Mendoza AJ, Díaz MDJO, Briones-Salas M (2004) Biodiversidad de Oaxaca. Instituto de Biología, UNAM, Mexico City, Mexico

GBIF Secretariat (2019) GBIF Backbone Taxonomy. http://gbif.org Accessed 23 July 2019

Gehrt SD, Riley SPD (2010) Coyotes (Canis latrans). In: Gehrt SD, Riley SPD, Cypher BL (eds) Urban Carnivores. John Hopkins University Press, Maryland, pp. 78-95

Girvetz E, Greco S (2007) How to define a patch: a spatial model for hierarchically delineating organism-specific habitat patches. Landscape Ecology 22:1131-1142

Gobierno del Estado de Oaxaca (2019) https : //www. oaxaca.gob.mx Accessed 3 October 2019

González-Maya JF, Zárrate-Charry DA, Cepeda AA, Balaguera-Reina SA, Benítez-Gutiérrez AM, Granados-Peña R, González M (2010) Diagnóstico, evaluación y propuestas de solución a la problemática de conflictos ocasionados por jaguar (Panthera onca) y puma (Puma concolor) a actividades pecuarias en jurisdicción de la Corporación Autónoma Regional del Cesar. CORPOCESAR, Departamento del Cesar, Colombia. Informe Técnico Final. ProCAT Colombia, CORPOCESAR, Valledupar, Cesar, Columbia

González-Maya JF, Romero-Rendón JF, ZárrateCharry C, Castaño-Uribe C, González M, Víquez-R LR, Arias-Alzate A (2013a) Evaluación geográfica y prioridades de conservación de hábitat para felinos en el Caribe colombiano. In: CastañoUribe C, González-Maya JF, Zárrate-Charry D, AngeJaramillo C, Vela-Vargas, IM (eds) Plan de Conservación de Felinos del Caribe colombiano: Los felinos y su papel en la planificación regional integral basada en especies clave. Fundación Herencia Ambiental Caribe, ProCAT Colombia, The Sierra to Sea Institute, Santa Marta, pp. 77-87

González-Maya JF, Zárrate CD, Cepeda AA, PinedaGuerrero A, Vela-Vargas IM, González M, CruzRodríguez, C (2013b) Ecología y conservación de felinos y presas en el Caribe colombiano. In: Castaño-Uribe C, González-Maya JF, Zárrate-Charry D, Ange-Jaramillo C, Vela-Vargas, IM (eds) Plan de Conservación de Felinos del Caribe colombiano: Los felinos y su papel en la planificación regional integral basada en especies clave. Fundación Herencia Ambiental Caribe, ProCAT Colombia, The Sierra to Sea Institute, Santa Marta, pp. 91-104

Granados-Peña R, Arias-Alzate A, Zárrate-Charry D, González-Maya JF (2014) Una estrategia de conservación a escala regional para el jaguar (Panthera onca) en el distrito biogeográfico de la Sierra Nevada de Santa Marta, Colombia. Revista Biodiversidad Neotropical 4:141-148

Graham K, Beckerman AP, Thirgood S (2005) Human-predator-prey conflicts: ecological correlates, prey losses and patterns of management. Biological Conservation 122:159-171 
Guerrero-Montes de Oca et al. 2021. Connecting worlds: indigenous territories, habitat suitability and conservation of three large carnivores (Mammalia: Carnivora) in southern Mexico

Ethnobio Conserv 10:26

Henestrosa A (2003) Los hombres que dispersó la danza. Porrúa, Mexico City. Mexico

Hidalgo-Mihart MG, Cantú-Salazar L, GonzálezRomero A, López-González CA (2004) Historical and present distribution of coyote (Canis latrans) in Mexico and Central America. Journal of Biogeography 31: 2025-2038

Hody AW, Moreno R, Meyer N, Pacifici K, Kays R (2019) Canid collision-expanding populations of coyotes (Canis latrans) and crabeating foxes (Cerdocyon thous) meet up in Panama. Journal of Mammalogy 100: 1819-1830

Hunter Jr ML (2005) A mesofilter conservation strategy to complement fine and coarse filters. Conservation Biology 19:1025-1029

INALI e INPI (2019) Atlas de los Pueblos Indígenas de México. http://atlas.cdi.gob.mx Accessed 20 August 2019

INEGI (2006) Red Hidrográfica digital de México, escala: 1:250 000. Dirección General de Geografía, Instituto Nacional de Estadística y Geografía, Instituto Nacional de Estadística y Geografía (INEGI), Aguascalientes, México

INEGI (2009) Uso del suelo y vegetación, escala 1:250 000, Serie IV (continuo nacional), escala: 1:250 000. Dirección General de Geografía, Instituto Nacional de Estadística y Geografía, Instituto Nacional de Estadística y Geografía (INEGI), Aguascalientes, México

INEGI (2013) Conjunto de datos vectoriales de uso de suelo y vegetación, escala 1:250 000, Serie V (Capa Unión), escala: 1:250 000. 2 ed. Instituto Nacional de Estadística y Geografía, Aguascalientes, México

INEGI (2015) Encuesta Intercensal 2015. Estimadores de la población total y su distribución porcentual según la base de datos de auto-adscripción indígena por municipio y grandes grupos de edad". Tabulados de la Encuesta Intercensal 2015 de INEGI. CDMX, México

INEGI (2016) Conjunto de datos vectoriales de uso de suelo y vegetación, escala 1:250 000, Serie VI (Capa Unión), escala: 1:250 000. 2 ed. Instituto Nacional de Estadística y Geografía, Aguascalientes, México

INEGI (2017a) Conociendo Oaxaca. 7 ed. Instituto Nacional de Estadística y Geografía, México

INEGI (2017b) Red nacional de caminos RNC. Dirección General de Geografía, Instituto Nacional de Estadística y Geografía, Instituto Nacional de Estadística y Geografía (INEGI), Aguascalientes, Méx- ico

Inskip C, Zimmermann A (2009) Human-felid conflicts: a review of patterns and priorities worldwide. Oryx 43:18-34

Irazoque E, Barbosa H (1962) Regiones fisiográficas de Oaxaca. Unpublished manuscript in Biblioteca Pública Central de Oaxaca, México

Knight AT, Cowling RM, Rouget M, Balmford A, Lombard AT, Campbell BM (2008) Knowing but not doing: selecting priority conservation areas and the research-implementation gap. Conservation biology 22:610-617.

LGEEPA. Ley General del Equilibrio Ecológico y la Protección al Ambiente (2008) Diario Oficial de la Federación, Estados Unidos Mexicanos, Presidencia de la República, México, 28 de enero de 1988. Derogado segundo párrafo, D.O.F. 16-05-2008

Lindenmayer DB, Franklin JF (2002) Conserving forest biodiversity: a comprehensive multiscaled approach. Island Press, Washington, USA

López Austin A (2012) Cosmovisión y pensamiento indígena. Conceptos y fenómenos fundamentales de nuestro tiempo. Instituto de Investigaciones Sociales, Universidad Nacional Autónoma de México, Mexico City, Mexico

López Austin A (2013) La fauna maravillosa de Mesoamérica. In: Millones L, López Austin A (eds) Fauna fantástica de Mesoamérica y los Andes. UNAM. Instituto de Investigaciones Antropológicas, Mexico City, pp. 31-91

Majka D, Jenness J, Beier P (2007) CorridorDesigner: ArcGIS tools for designing and evaluating corridors. Environmental Research, Development and Education for the New Economy (ERDENE), Northern Arizona University, Flagstaff AZ [http:// corridordesign.org]

Martin GJ, Camacho CI, del Campo C, Anta S, Chapela F, González MA (2011) Indigenous and community conserved areas in Oaxaca, Mexico. Management of Environmental Quality: An International Journal, 22, 250-266

Martinez-Alier J, Munda G, O'Neill J (1998) Weak comparability of values as a foundation for ecological economics. Ecological economics 26:277-286

Mech LD (1970) The Wolf: The Ecology and Behavior of an Endangered Species. The American Museum of Natural History/The Natural History Press, Garden City, New York, USA 
Guerrero-Montes de Oca et al. 2021. Connecting worlds: indigenous territories, habitat suitability and conservation of three large carnivores (Mammalia: Carnivora) in southern Mexico

Ethnobio Conserv 10:26

Millar JRB, Jhava JV, Schmidtz OJ (2016) Human Perceptions Mirror Realities of Carnivore Attack Risk for Livestock: Implications for Mitigating Human-Carnivore Conflict. PLoSOne doi: 10.1371/journal.pone.0162685.

Munda G (2005) Multiple criteria decision analysis and sustainable development. In: Greco S (ed) Multiple criteria decision analysis: State of the art surveys. Springer, New York, pp. 953-986

Monroy-Gamboa AG, Sánchez-Cordero V, BrionesSalas MA, Lira-Saade R, and Maass JM (2015) Representatividad de los tipos de vegetación en distintas iniciativas de conservación en Oaxaca, México. Bosque (Valdivia) 36:199-210

Monroy-Gamboa AG, Briones-Salas MA, Sarkar S, and Sánchez-Cordero V (2019) Terrestrial vertebrates as surrogates for selecting conservation areas in a biodiversity hotspot in Mexico. Conservation Science and Practice doi: 10.1111/csp2.12.

Olivier G (2016) Dioses y Jaguares. Artes de México 121:48-54

Penrod K, Spencer W, Rubin E, Paulman C (2010) Habitat Connectivity Planning for Selected Focal Species in the Carrizo Plain. Prepared for County of San Luis Obispo by SC Wildlands. http://www.scwildlands.org/reports/ CarrizoConnectivity.pdf Accessed 22 February 2021.

R Core Team (2015) R: A Language and Environment for Statistical Computing, Vienna, Austria

Ray JC (2005) Large carnivorous animals as tools for conserving biodiversity: assumptions and uncertainties. In: Ray J, Redford, KH, Steneck $\mathrm{R}$, Berger J (eds) Large Carnivores and the Conservation of Biodiversity, pp. 34-56

Redford, KH (1992) The Empty Forest. BioScience 42:412-422

Ripple WJ, Estes JA, Beschta RL, Wilmers, CC, Ritchie, EG, Hebblewhite M, Berger J, Elmhagen B, Letnic M, Nelson MP, Schmitz OJ, Smith DW, Wallach AD, Wirsing, AJ (2014) Status and Ecological Effects of the World's Largest Carnivores. Science doi: 10.1126/science.1241484.

Rondinini C, Di Marco M, Chiozza F, Santulli G, Baisero D, Visconti P, Hoffmann M, Schipper J, Stuart SN, Tognelli MF, Amori G, Falcucci A, Maiorano L, Boitani L (2011) Global habitat suitability models of terrestrial mammals. Philosophical Transactions of the Royal Society B: Biological
Sciences 366(1578):2633-2641

Ruan-Soto F, Figueroa D, Santos-Fita D, CastilloHuitrón N, Basante A, García del Valle Y, ReyesEscutia F (2018) Etnobiología y conservación: el concepto de importancia cultural para entender la relación entre humanos y grandes depredadores. In: Monroy Vilchis O, Zarco Urios V, Moliner M, Zarco González, M (eds) Situación Actual De Los Grandes Depredadores. 1 ed. Mexico City, pp. 155-180

Sahagún, FB (2005) Fauna de la Nueva España. Fondo de Cultura Económica, Mexico City, Mexico

Sánchez DG, Durán IP (2018) El coyote protagonista de la cosmogonía otomí-mazahua. Un análisis desde los mitos de la creación. Mitológicas 33:23-34

Sanderson EW, Redford KH, Chetkiewicz CLB, Medellin RA, Rabinowitz AR, Robinson JG, Taber AB (2002) Planning to save a species: the jaguar as a model. Conservation Biology 16:58-72

Saunders NJ (1994) Predators of culture: Jaguar symbolism and Mesoamerican elites. World Archaeology 26:104-117

Seller E (2004) Las imágenes de animales en los manuscritos mexicanos y mayas. Casa Juan Pablos, Mexico City, Mexico

Schaller GB, Crawshaw Jr PG (1980) Movement Patterns of Jaguar. Biotropica 12:161-168

Stevens SF (1997) Conservation through Cultural Survival: Indigenous Peoples and Protected Areas. Island Press

Sugiyama N (2016) La noche y el día en Teotihuacán. Artes de México 121:30-35

Tecle U, Duckstein L (1993) Concepts of multicriteria decision making. In: Bogardi JJ, Nachtnebel, HP (eds) Multicriteria Decision Analysis in Water Resources Management. 1ed. UNESCO, pp. 33-62

Toledo VM (2001) Indigenous peoples and biodiversity. Encyclopedia of biodiversity, 3:451-463

Toledo VM, Barrera-Bassols N (2008) La memoria biocultural: la importancia ecológica de las sabidurías tradicionales. Vol. 3. Icaria editorial, Barcelona, Spain

Treves A, Karanth KU (2003) Human-carnivore conflict and perspectives on carnivore management worldwide. Conservation Biology 17:14911499

UN (2019) Día Mundial del Medio Ambiente, 5 de junio. https://www.un.org/es/events/ 
environmentday/background.shtml Accessed 7 September 2019

Vela E (2010) Introducción. Culturas prehispánicas de México. Arqueología Mexicana 34:6-8

Wilson KA, Evans MC, Di Marco M, Green DC, Boitani L, Possingham HP, Rondinini C (2011) Prioritizing conservation investments for mammal species globally. Philosophical Transactions of the Royal Society. B: Biological Sciences 366:2670-2680

Williams ST, Maree N, Taylor P, Belmain SR, Keith M, Swanepoel LH (2018) Predation by small mammalian carnivores in rural agroecosystems: An undervalued ecosystem service? Ecosystem Services 30:362-371

\section{Worldclim (2019) The SRTM elevation}

database (aggregeated to 30 arc-seconds, "1 km") [https://www.worldclim.org/methods1]

WWF México (2019) Oaxaca. https://www.wwf. org.mx/que_hacemos/programas/oaxaca Accessed 1 October 2019

Zouche-Nutall Codex (1987) Codex ZoucheNutall. Codices Selecti 84. Akademische Druck und Verlagsanstalt, Graz, Austria. https://www. famsi.org.

Received: 10 November 2020

Accepted: 15 May 2021

Published: 05 July 2021 


\section{Additional Files}
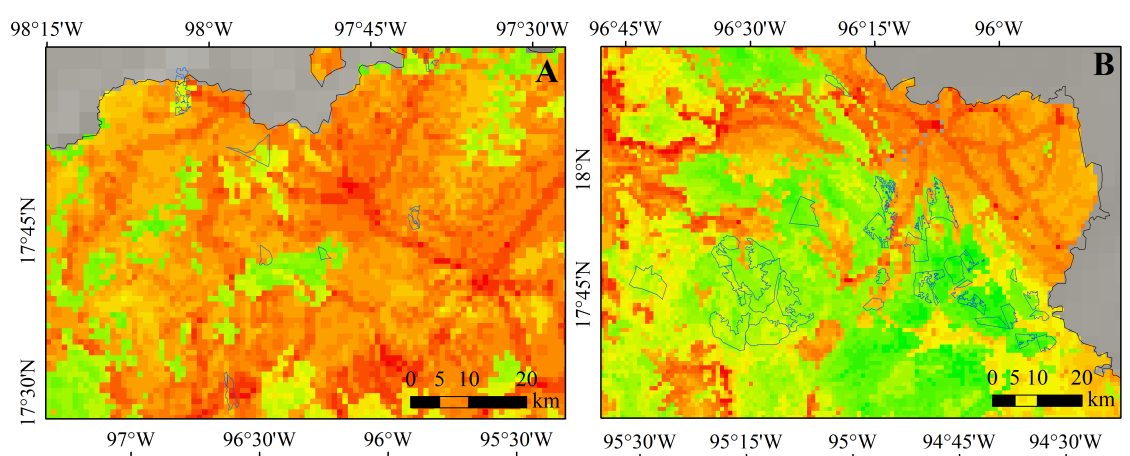

\section{Habitat suitability}
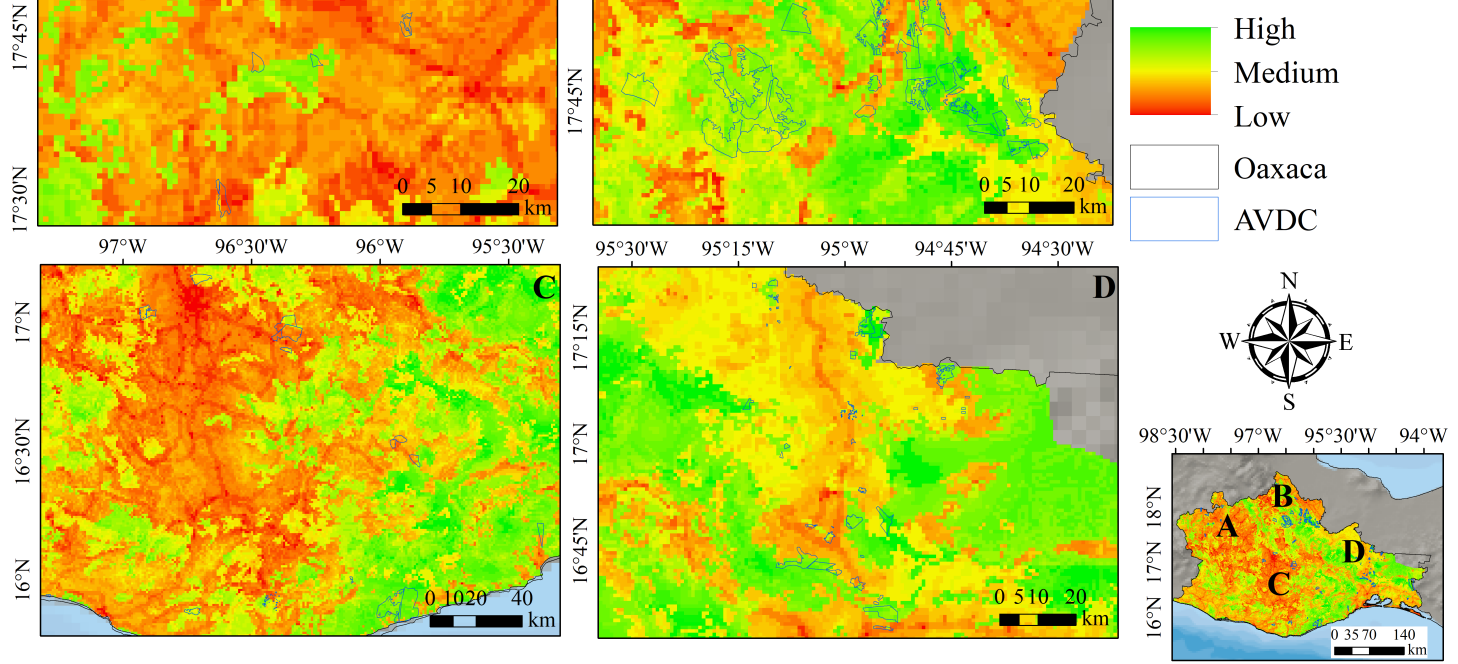

Add File 1. A closer view of high, medium, and low jaguar habitat suitability trend for the LULC 2009 and its relationship with the Areas Voluntarily Designated for Conservation (AVDC in blue). 
Guerrero-Montes de Oca et al. 2021. Connecting worlds: indigenous territories, habitat suitability and conservation of three large carnivores (Mammalia: Carnivora) in southern Mexico

Ethnobio Conserv 10:26
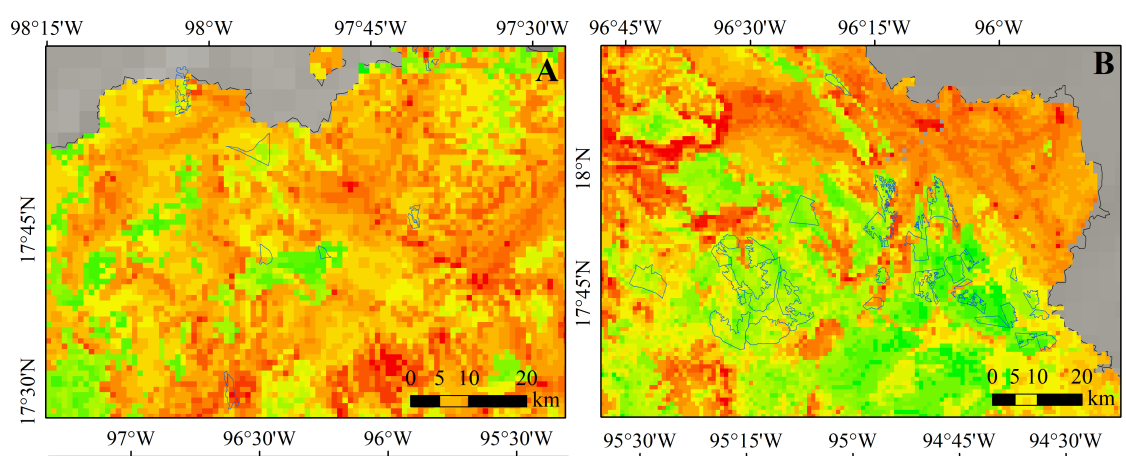

\section{Habitat suitability}
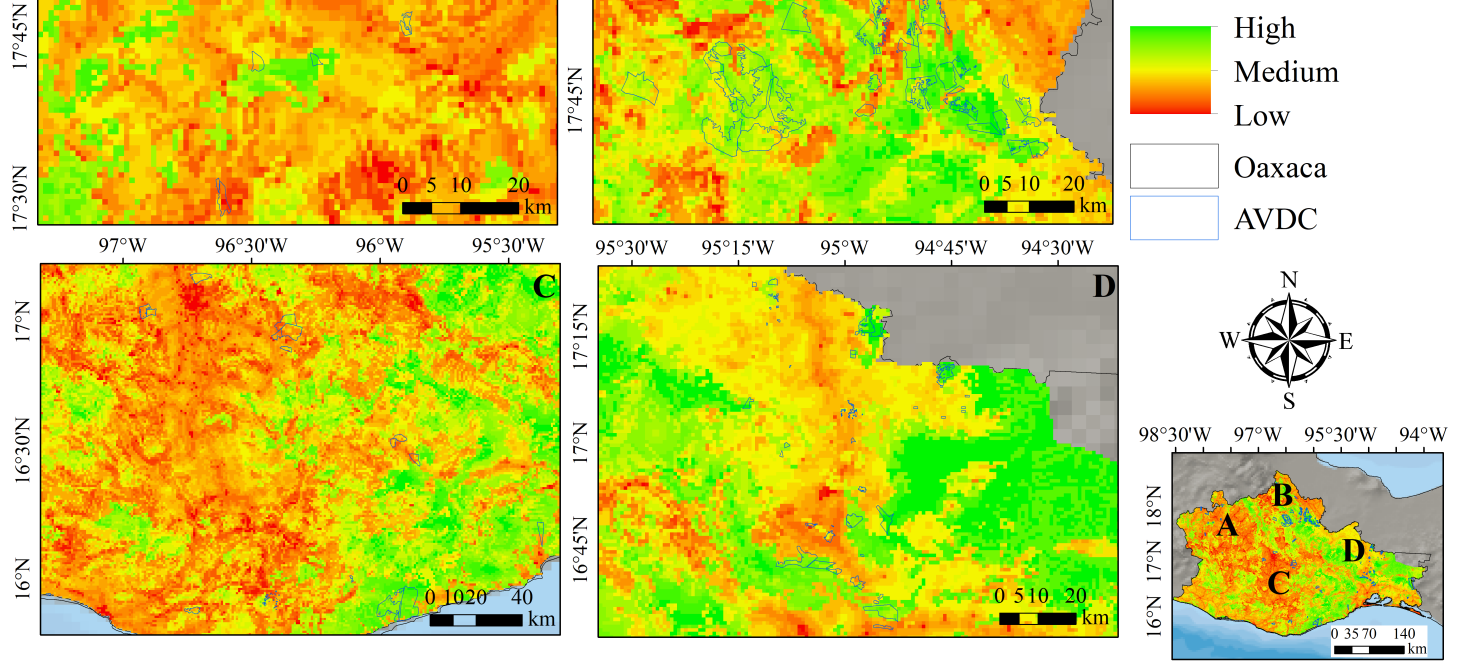

Add File 2. A closer view of high, medium, and low puma habitat suitability trend for the LULC 2009 and its relationship with the Areas Voluntarily Designated for Conservation (AVDC in blue).

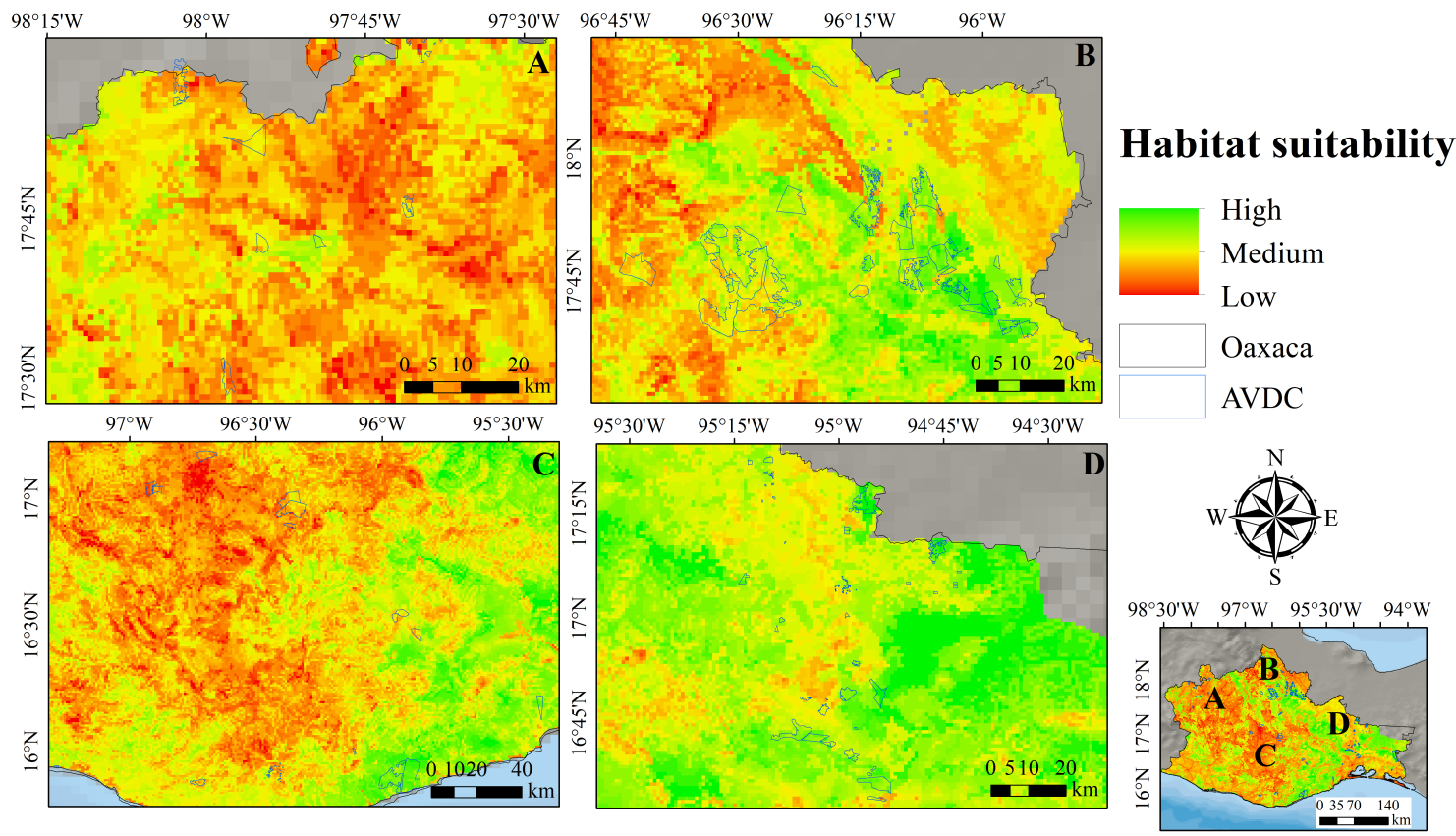

Add File 3. A closer view of high, medium, and low coyote habitat suitability trend for the LULC 2009 and its relationship with the Areas Voluntarily Designated for Conservation (AVDC in blue). 